\title{
Conversion of Polytechnics to Technical Universities in Ghana; The Way Forward for Mechanical Engineering Students
}

\author{
Esther Benedicta Kyere \\ Lecturer, Department of Automotive, Refrigeration and Air Conditioning Engineering, Takoradi Technical University, Western Region
} (Ghana)

\begin{abstract}
No nation can grow, economically or socially, without significant and sustained investments in the knowledge and skills of its people [1]. Ghana being in deep crisis for the last few years requires a new generation of engineers appropriately skilled to enforce and support the expected growth. Mechanical engineering field is one of the basic and crucial sectors and should be equipped with the proper manpower. Therefore, the association between mechanical graduate studies and industrial practical training will be the key to providing the higher-level skills that are required for economic recovery and long-term prosperity; but Industrial practical training of mechanical Engineering students in the Polytechnics(now Technical Universities) in Ghana is facing many challenges. The problems ranging from obsolete and inadequate training equipment and tools, lack of training materials, inadequate number of qualified instructors with requisite industrial practical experience, lack of linkage between training institutions and industry and lack of relevance of institutional training to the needs of industry. The main aim of this study is to establish whether the industrial practical training of mechanical engineering students during their studies helps them to gain several professional skills that are required for economic recovery. To reach conclusions regarding these critical issues, a survey was conducted through questionnaires distributed to students of the Department of Mechanical Engineering of the Southern Technical Universities in Ghana. Students were asked to analysed the contribution of the industrial practical training exercise during their studies to their professional abilities. In this paper, these challenges confronting industrial practical training of mechanical engineering students are discussed with the aim of recommending ways of addressing them in the Technical Universities.
\end{abstract}

Keywords: Industrial Practical training, Mechanical engineering, Technical universities, Skills, Polytechnics, Ghana

\section{Introduction}

The reputation of TVE (Technical Vocational Education) institutions is dependent on their ability to produce qualified young people who will be immediately operational in the work place [2]. There is an increasing demand from the industrial sector, and a similar desire by academics, to offer more professional practice skills and experiences to graduates of mechanical engineering programs. Many observers trace the missing link in Ghana's industrial development to the neglect of technical and vocational education and training [3]. Although, TVE is recognized as an important sub- sector for the attainment of the industrial development in Ghana, the training content at some levels are outdated and the quality of teaching and learning has continued to decline. Ghana, desirous of achieving industrial development Goals as stated in the Ghana vision 2020 plan, it is believed, cannot achieve any meaningful results without paying attention to technical and vocational education at all levels. At present, teaching takes place mainly in the form of head-on learning by teachers. Many of the TVE learning centres, especially the Polytechnics, are unable to combine theoretical training with practical exposure to produce qualified graduates for direct absorption into industry. There is a need therefore for strong industry collaboration and improved practical training in industry as well as a platform for seconding staff in the technical and vocational institutes especially the Polytechnics (now Technical Universities) to gain some useful practical experience in industry to improve teaching and learning. The recent emphasis on CompetencyBased Training (CBT) system is to enhance relevance of technical vocational education and ensure that training is guided by competencies endorsed by industry so that TVE graduates would acquire and demonstrate skills that meet the needs and specific standards of industry. This necessity for more practical training is not only understood and admitted by industry and teachers, but by the candidate engineers as well. Nowadays, competitiveness and technological innovation is driving the requirement for bridging the gap between theory and practice within the engineering curriculum [4]. Within this highly completive environment, students should be exposed for an appropriate period to important practical experiences, which simulate the reality of the engineering profession to develop wider skills and attributes, including team-working, communication, leadership, critical thinking and problem-solving. These are commonly known as employability skills [5]. In Ghana, the engineering curriculum is too theory oriented that it is tough for the students to acquire the adequate skills required by the industries.

Industrial training is a necessary module of engineering curricula to provide well prepared graduates for industries [6]. An experience within industry practice is necessary for students to obtain employability skills. An introvert faculty distant from industrial reality will miss on significant prospects to adapt the curriculum to meet the industrial needs [7].

In modern times, professional skills are considered extremely important by both the graduates and the employees as well. Most companies request engineering graduates who have gained adequate theoretical knowledge and simultaneously have specific professional skills [8] [9]. Industry is seeking graduates who have experience with team- working skills

Volume 6 Issue 12, December 2017 


\section{International Journal of Science and Research (IJSR) \\ ISSN (Online): 2319-7064}

Index Copernicus Value (2016): 79.57 | Impact Factor (2015): 6.391

and technical sector-specific skills [10]. On the other hand, there are many complaints about unemployment by graduates because of the lack of such skills [11].

Skill is the ability to do something that has been learnt [12]. Consequently, a skill requires some knowledge that is combined with some knowledge how [12] [13]. According to Eraut, professional skills especially, require unique combinations of propositional knowledge, situational knowledge and professional judgment [14]. Inevitably, professional skills may be learned through education techniques combined with practical training and experience [12-14]. In general, skills could be categorized into cognitive skills, which are associated with the theoretical knowledge background and way of thinking, and practical skills, which are related with the applied use of methods, materials and tools. It is therefore very important that Mechanical Engineering students gain professional skills through their studies to enhance their employability.

\subsection{Conversion of Polytechnics into Technical Universities (TU's)}

His Excellency, the President of the Republic of Ghana, in his 2013 State of the Nation address, announced that the Polytechnics will be converted to Technical Universities. Students in the Technical Universities will be trained to acquire high level technical skills to drive the country's economic and national development agenda. The proposed technical universities would contribute to raising the quality and competitiveness of the Ghanaian workforce by providing opportunities for company employees to upgrade their skills and acquire new skills. The new Technical Universities would reduce the admission pressures on the traditional universities, provide progression avenues for technical and vocational students, and curb the growing phenomenon of academic-type "top-up" programmes for HND graduates at the traditional universities. Technical Universities, having a different focus and orientation from traditional universities, will contribute to creating a more diverse and better performing higher education system.

Polytechnic education emphasises the application of knowledge rather than the search for new knowledge. The thrust of polytechnic training is, therefore, on the acquisition of the relevant skills required to perform specific professional tasks without ignoring the underlying theoretical knowledge necessary for a proper understanding of the tasks to be performed whereas the BTech programmes introduce to be taught in the Technical Universities are expected to deepen the practical orientation of the HND qualification and provide HND graduates with advanced technical knowledge and skills as well as offer them a more logical avenue for academic and professional progression. The running of degree programmes also is expected to improve the public image of the polytechnics. Now that the Polytechnics are converted to Technical Universities, are mechanical engineering students trained to acquire high level technical skills to drive the country's economic and national development agenda?

\section{Materials and Methods}

A survey research design was used in this study to elicit opinion from respondents. The study was conducted in Takoradi Technical University, western region, Cape Coast Technical University, in the central region, Accra Technical University, in the greater Accra region and the Koforidua Technical University in the eastern region of Ghana. The population for this study comprised of third year students of the four options of the mechanical engineering department. Therefore, total population for this study was 160; which comprised purposively sampled third year mechanical engineering students from all the Technical Universities mentioned above. The population of the study was considered as the sample. Structured questionnaires were used to collect data from the respondents. The analysis of the data was accomplished by using the mode. The mode of each item was interpreted in relation to the real limits of values assigned to the response categories of the instruments (Table $1)$.

Table 1: Response categories of the instrument used

\begin{tabular}{|c|c|}
\hline Responses & Value \\
\hline Strongly Agree & 1 \\
\hline Agree & 2 \\
\hline Disagree & 3 \\
\hline Strongly disagree & 4 \\
\hline
\end{tabular}

Data were collected by distributing questionnaires to final year students of the Department of Mechanical Engineering at the Technical Universities in the Southern part of Ghana. The surveyed students almost equivalently followed one of the four available options of the Mechanical Engineering programme; namely, Plant, Production, Refrigeration and Air conditioning and Automotive engineering. Their practical exercise took place during their years of studies and their industrial training attheend of their first and second semesters of their studies in work places of various profiles, most of them associated with heavy industry and very few with smaller technical companies. The survey explored students' perceptions of the benefits and barriers of the industrial practical exercise. Participation in the survey was voluntary. In all, a total of 140 out of the 160 respondents selected effectively participated in the study. The data presented below correspond to asample size of 140 students. Table 2 shows student's opinion about skills that employers in Ghana companies require to employ higher education graduates. The skills that were analysed were in the following areas: measuring, bench work, machining, welding, forging and metal fabrication; Table 3 shows mechanical engineering students' perspective about the Technical Universities and the way forward whiles Table 4 shows mechanical engineering students' perception about industrial training.

\section{Results}

The results of the analysis of the data for the survey are presented in tables 2-4. 


\section{International Journal of Science and Research (IJSR) \\ ISSN (Online): 2319-7064}

Index Copernicus Value (2016): 79.57 | Impact Factor (2015): 6.391

Table 2: Occupational skills acquired by Students of the Polytechnics

\begin{tabular}{|c|c|c|}
\hline Skills in measuring & $\mathrm{N}$ & Mode \\
\hline $\begin{array}{l}\text { 1.I can confidently use the following measuring } \\
\text { instruments: dial gauge, micrometer, Vernier caliper }\end{array}$ & 140 & 2 \\
\hline \multicolumn{3}{|l|}{\begin{tabular}{|c|} 
Skills in bench work \\
\end{tabular}} \\
\hline $\begin{array}{l}\text { 2.I can confidently do filling, riveting and tool } \\
\text { grinding }\end{array}$ & 140 & 2 \\
\hline \multicolumn{3}{|l|}{ Skills in machining } \\
\hline $\begin{array}{l}\text { 3. I can operate the milling machine, lathe machine, } \\
\text { drilling mill, threading machine and the shaping. }\end{array}$ & 140 & 3 \\
\hline $\begin{array}{l}\text { 4.I can maintain machines and equipment in the } \\
\text { workshop }\end{array}$ & 140 & 4 \\
\hline \multicolumn{3}{|l|}{$\begin{array}{c}\text { Skills in welding } \\
\end{array}$} \\
\hline $\begin{array}{l}\text { 5. I can handle the electrode holder in Arc welding } \\
\text { operation }\end{array}$ & 140 & 2 \\
\hline $\begin{array}{l}\text { 6. I can set the valves on the blow pipe in gas } \\
\text { welding operation }\end{array}$ & 140 & 2 \\
\hline $\begin{array}{l}\text { 7. I am conversant with leftward and rightward } \\
\text { welding techniques }\end{array}$ & 140 & 4 \\
\hline \multicolumn{3}{|l|}{$\begin{array}{l}\text { Skills in forging } \\
\end{array}$} \\
\hline $\begin{array}{c}\text { 8.I can do annealing process, heating process and } \\
\text { normalizing process in forging }\end{array}$ & 140 & 3 \\
\hline \multicolumn{3}{|l|}{ Skills in metal fabrication } \\
\hline $\begin{array}{l}\text { 9. I can confidently do metal forming, folding and } \\
\text { normalizing in fabrication work }\end{array}$ & 140 & 4 \\
\hline \multicolumn{3}{|l|}{ New and emerging skills } \\
\hline 10. I can express myself in English language & 140 & 1 \\
\hline 11. I can make sound decision & 140 & 2 \\
\hline $\begin{array}{l}\text { 12. I understand PLC/inverter operation in } \\
\text { mechanical machines }\end{array}$ & 140 & 3 \\
\hline 13. I can read and draw the mechanical drawing & 140 & 3 \\
\hline $\begin{array}{l}\text { 14. I can read the different views of Auto CAD } \\
\text { drawings }\end{array}$ & 130 & 3 \\
\hline $\begin{array}{l}\text { 15.I can confidently operate a computerized lathe } \\
\text { machine }\end{array}$ & 130 & 4 \\
\hline 16.I can do estimates about a drawing & 130 & 3 \\
\hline 17. I can use the computer for technical reports & 130 & 2 \\
\hline $\begin{array}{l}\text { 18. I can operate computerized lathe/milling } \\
\text { machine }\end{array}$ & 130 & 3 \\
\hline
\end{tabular}

The data represented in Table 2 , reveals that all the technical skills identified are always acquired in the Polytechnics except for items 3, 4, 7, 8, 9, 12, 13, 15, 16 , and 18 which are never acquired in the Polytechnics. The data shows that students in the Polytechnic never acquired skills in maintaining equipment /machine in workshop, computerized Lathe machine operation and repairing of Lathe machine.

Mechanical engineering students in the Polytechnic institutes acquired skills in mechanical engineering in the following tasks: measuring and reading of the micrometer, Bench work-filing, riveting, Lathe machine operation, welding power handling of electrode holder, forging annealing, heating process and Skills in metal fabrication forming etc.

Table 3: Students perspective about TU's and the way forward

\begin{tabular}{|c|c|c|}
\hline $\begin{array}{c}\text { Students Perspective about the conversion of } \\
\text { Polytechnics to TU }\end{array}$ & $\mathrm{N}$ & Mode \\
\hline $\begin{array}{c}\text { 1.Converting the Polytechnic into Technical } \\
\text { Universities is a big mistake }\end{array}$ & 140 & 3 \\
\hline $\begin{array}{c}\text { 2. My lecturers were only interested in teaching } \\
\text { theory, not practical training }\end{array}$ & 140 & 1 \\
\hline 3.Only practical and professional trainers are & 140 & 1 \\
\hline
\end{tabular}

\begin{tabular}{|c|c|c|} 
needed to teach in the Technical University(TU) & & \\
\hline $\begin{array}{c}\text { 4. A mixture of theory and industrial skills will be } \\
\text { best for handling students in the TU's }\end{array}$ & 140 & 1 \\
\hline $\begin{array}{c}\text { 5.Both technicians and lecturers will have to work } \\
\text { together this time to train in the TU's. }\end{array}$ & 140 & 1 \\
\hline $\begin{array}{c}\text { 6.For the Technical University to succeed, lecturers } \\
\text { must reduce the theory content for more practical } \\
\text { training }\end{array}$ & 140 & 1 \\
\hline $\begin{array}{c}\text { 7. The Technical universities will need more } \\
\text { laboratories and workshops than lecture room/halls }\end{array}$ & 140 & 1 \\
\hline $\begin{array}{c}\text { 8. It is likely that Technical Universities will need } \\
\text { skill trainers in the engineering faculties }\end{array}$ & 140 & 1 \\
\hline $\begin{array}{c}\text { 9. Technical Universities will need collaboration } \\
\text { with industry as teachers/trainers }\end{array}$ & 140 & 1 \\
\hline $\begin{array}{c}\text { 10.To succeed, TU's need more workshop } \\
\text { practicals, laboratories work, industrial visits and } \\
\text { industrial attachments }\end{array}$ & 140 & 1 \\
\hline $\begin{array}{c}\text { 11.The machines in the university workshop are } \\
\text { only there for exhibition, not for students' use }\end{array}$ & 140 & 1 \\
\hline $\begin{array}{c}\text { 12. The timetable on practical training during my } \\
\text { course was adequately utilized for practical training }\end{array}$ & 140 & 4 \\
\hline $\begin{array}{c}\text { 13. The mechanical engineering workshops have } \\
\text { enough machines and tools to train students }\end{array}$ & 140 & 4 \\
\hline $\begin{array}{c}\text { 14. There should be a policy that students be } \\
\text { examined in workshop practical training }\end{array}$ & 140 & 1 \\
\hline
\end{tabular}

Table 3 indicates that most of the students are happy about the conversion of the Polytechnics into Technical Universities. But they indicated that the Technical Universities would need more laboratories and workshops to enable the lecturers to reduce teaching more theory than practical training. The respondents also suggested that a mixture of theory and practicals would be best for Technical Universities and professional and skilled trainers would be preferred as lecturers.

Table 4: Students perception about Industrial attachment

\begin{tabular}{|c|c|c|}
\hline Skills acquired during industrial attachment & $\mathrm{N}$ & Mode \\
\hline $\begin{array}{c}\text { 1. I saw most of the machines given in } \\
\text { theory during my attachment }\end{array}$ & 140 & 2 \\
\hline $\begin{array}{c}\text { 2.During the industrial attachment, I had full } \\
\text { benefit of operating their machines and } \\
\text { equipment }\end{array}$ & 140 & 1 \\
\hline $\begin{array}{c}\text { 3.The industrial attachment made impact on } \\
\text { my training }\end{array}$ & 140 & 1 \\
\hline $\begin{array}{c}\text { 4 Arrangement for the industrial attachment } \\
\text { was excellent }\end{array}$ & 140 & 1 \\
\hline $\begin{array}{c}\text { 5. I could use some of the machines during } \\
\text { my industrial attachment }\end{array}$ & 140 & 1 \\
\hline $\begin{array}{c}\text { 6. The industrial attachment made impact on } \\
\text { my training }\end{array}$ & 140 & 1 \\
\hline $\begin{array}{c}\text { 7.Arrangement for the industrial attachment } \\
\text { was excellent }\end{array}$ & 140 & 1 \\
\hline
\end{tabular}

Table 4 presents the mechanical engineering students' perspective about the contribution of the practical training experience during their industrial attachment. Most of the students had the opportunity to operate machines and equipment thereby acquiring their practical experience during industrial attachment. They believe that the practical exercise helped them significantly to adapt to and act in new situations, such as a new workplace environment.

\section{Discussion}

From the above analysis, it can be concluded that students

\section{Volume 6 Issue 12, December 2017}




\section{International Journal of Science and Research (IJSR) \\ ISSN (Online): 2319-7064}

Index Copernicus Value (2016): 79.57 | Impact Factor (2015): 6.391

in Mechanical engineering acquire knowledge in the following:

Measuring, that is reading the micrometer, reading the dial indicator, using feeler gauge, filing, riveting, tool grinding, lathe machine operation, threading operation, milling machine operation, maintaining equipment/machine in workshop, proper handling of electrode holder in arc welding operation, accurate setting of valves on the blow pipe in oxy-acetylene welding operation, annealing, heating and normalizing process in forging.

The respondents considered most of the skills in new and emerging occupations as never acquired in the polytechnics. Such skills as Computerized lathe machine operation, repairing of lathe machine, setting in printing operation. It can be implied that the traditional skills acquired in the polytechnic institutes are required by industries for menial jobs.

As it can be seen from the mode of each item in tables 2 , 3 and 4 of the survey instrument, all the correspondents covertly acknowledged that there are deficiencies in the skills acquired in the polytechnics. The respondents agreed that the deficiencies include the lack of co-operative industrial participation and adequate contribution to polytechnic institute which should have come through joint sharing of training facilities, encouragement of technical instructors to participate in industrial attachment and supervision of students on training.

The respondents generally agreed that the major remedy to the deficiencies in skills acquired in polytechnic institutes is to establish a mutual relationship between the industrials and the Polytechnic Institute by jointly involving them to draw up training programme for Polytechnics, encouraging technical instructors to participate in industrial attachment, encouraging professionals on part time basis, sharing of training facilities and internship pattern for training.

\subsection{Way forward for Mechanical Engineering students in the Technical Universities}

For Mechanical engineering in the Technical Universities to be more competency based, the following suggested remedies for the deficiencies in the skills acquired in the Polytechnics should be adopted:

1) Placement of students on part-time work

2) Provision or supply of training equipment

3) Encouraging teachers to engage in industrial attachment

4) Setting up short courses for upgrading skills

5) Drawing up training programme (curriculum) for the Technical Universities

6) Forming industrial advisory committees

7) Setting up standards of proficiency to be met by trainees

8) Organizing seminars, workshops and conference

9) Provision of vocational guidance to trainees

10) Sharing of training facilities

11) Setting up short courses for updating skills

12) Cross training/teaching
13) Provision of in-service training for employees

14) Establishing industrial coordinating units

15) Organizing plant or field trips for trainees and counselors

16) Supervision of students on training

17) Forming occupational committees

18) Encouraging professionals on part-time basis

19) The Mechanical Engineering Departments should develop a small workshop to develop the skills for students and for the Department.

\section{Conclusion/ Recommendation}

From the findings, it can be recommended that the technical education board with collaboration with experts from industries and government organization should draw up the current curriculum for Technical Universities programme in line with the new emerging skills from the industries and should be re-oriented towards practical knowledge and art of doing things.

Also, Industries should jointly engage in skills acquisition through sharing of training facilities, encouraging technical instructors to observe industrial attachment for a period not less than six months every three years. Professionals in industrials should be encouraged to teach in the Technical Universities on part time basis, and students should be placed on part time work. Technical instructors, industrialists and education planners would jointly organize a plan technical training programmes to correct the deficiencies in skills acquired in the Polytechnic Institutes to produce graduates with saleable and employable skills.

\section{References}

[1] Bailey,T.R.,LearningtoWork:EmployerInvolvementinS chool-to-WorkTransitionPrograms. Washington,DC: TheBrookingsInstitution(1995).

[2] SpecialIssueonTheoryandPracticeGap,IEEEControlSys temMagazine, 19(1999).

[3] Nsiah-Gyabaah, K. (2009) The Missing Ingredients in Technical and Vocational Education in Meeting the Needs of Society and Promoting Socio-Economic Development in Ghana; Journal of Polytechnics in Ghana; Volume 3, No. 3

[4] SpecialIssueonTheoryandPracticeGap,IEEEControlSys temMagazine, 19(1999).

[5] Bhaerman,R.andSpill, R.,A dialogueon employability skills: how can they be taught?J. of Career Develop.,15, 1, 41-52(1988).

[6] Yusoff,Y.M.,Omar,M.Z.,Zaharim,A.,Mohamed,A., Muhamad, N.and Mustapha,R., Enhancingemployability skillsthroughindustrialtrainingprogramme. Proc. Inter. Conf. on Engng. Educ. And Inter. Conf. on Educ.and EducationalTechnologies,398-403(2010).

[7] Powell,R.A.,Integratingpracticeintoengineeringeducatio n.Proc.ASEEAnnualConf.andExposition, 8437 8449(2005).

[8] Omar,N.H.,Manaf,A.A.,Mohd,R.H.,Kassim,A.C.andAz iz,K.A.,Graduates'employabilityskillsbasedon current job demand through electronic advertisement. Asian Social Science,8,9, 103-110(2012).

[9] Harvey, L., Newrealities: the relationshipbetween

Volume 6 Issue 12, December 2017 


\section{International Journal of Science and Research (IJSR) \\ ISSN (Online): 2319-7064}

Index Copernicus Value (2016): 79.57 | Impact Factor (2015): 6.391

higher educationand employment.Tertiary Educ.and Manage.,6, 3-17(2000).

[10] The Gallup Organization, Employers' Perception of Graduate Employability (Analysis Report No. Flash EB No.304), The Gallup Organization, Brussels (2010).

[11] Selvadurai, S., Choy E.A. and Maros, M., Generic skills of prospective graduates from the employers' perspectives. Asian Social Science, 8, 12, 295-303 (2012).

[12] Moon,J.A.,A Handbook of eflective and Experiential Learning. London, New York: Routledge Falmer(2004).

[13] Eraut,M.,Developing ProfessionalKnowledgeand Competence. London: The FalmerPress(1994).

[14] Tether,B.,Mina,A.,Consoli,D.andGagliardi,D.,ALiteratu reReviewonSkillsandInnovation.Manchester: ESRC ResearchCentrefor ResearchonInnovationand Competition(2005).

\section{Authors Profile}

Esther Benedicta Kyere had her Master of Technology (Mtech) degree in 2012 from University of Education Ghana and BSc degree in Mechanical Engineering from Kwame Nkrumah University of Science and Technology, Ghana in 2009. She attained a Higher National Diploma (HND) in Refrigerationand Air-conditioning Engineering from Takoradi Technical University in 2001. She is currently a lecturer for Refrigeration and Air-conditioning Engineering at the Takoradi Technical University in Ghana 